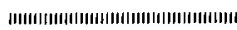

\title{
ゾーン法による連続亜鉛メッキ設備無酸化炉 の伝熱解析
}

\author{
陣内秀信 ${ }^{*}$, 端田博則*, 宮谷仁士*, 山本耕太郎*
}

\section{An Analysis of Heat Transmission on the Non-oxidiz- ing Furnace in the Continuous Galvanizing Line by Zone Method}

\author{
Hidenobu Jinnouchi, Hironori Satta, Hitoshi Miyatani \\ and Kohtaro Yamamoto
}

\begin{abstract}
Synopsis
Zone method formulated by H.C. Hottel and others is varid to solve radiative heat transmission within the enclosure containing gas inside.

This method has been applied to various thermal processes as high speed computer progresses.

Authors have developed a program for the non-oxidizing furnace in the continuous galvanizing line by this method.

In this paper, fundamental formulae are explained, and calculated results for changes in various parameters such as height of the furnace, strip width, emissivities of strip or refractory and others are discussed.
\end{abstract}

\section{1. 緒言}

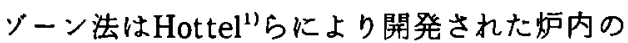
放射伝熱の解析法であるが，その計算の繁雑さか ら，なかなか一般に使用されるまでに至らなかっ た。しかし，近年省エネルギー化あるいは製品の 高品質化などの二ーズに対する設備の最適設計の 必要性とコンピュータの急速な大形化・高速化が 可能になったことが相まって, ポイラ、工業䉆炉 などの伝熱解析 ${ }^{21,3}$ に徐々に適用されるよ5にな

昭和59年 7 月 12 日受付

“大同特殊鋼妹嘰械事業部設計部
ってきた。

ここでは，ゾーン法を鋼板の連続覀鉛メッキ設 備 (CGL) のなかの無酸化炬に適用し, 炬形状, 炉壁・鋼板の放射率，空気比などの変化が炉の性 能にどのように影響するか試算した。

2. ソ゚ーン法による伝熱解析

2.1 解析モテル

CGLは熱間圧延された鋼板を焼鈍し，覀鉛メッ キする設備である。その中で無酸化炉は最も上流 側に位置し，鋼板をハースロールにより連続的に 搬送しながら所定の温度まで加熱するるのであ る。無酸化炉はNOF (加熱帯) と PHF (予熱帯) 

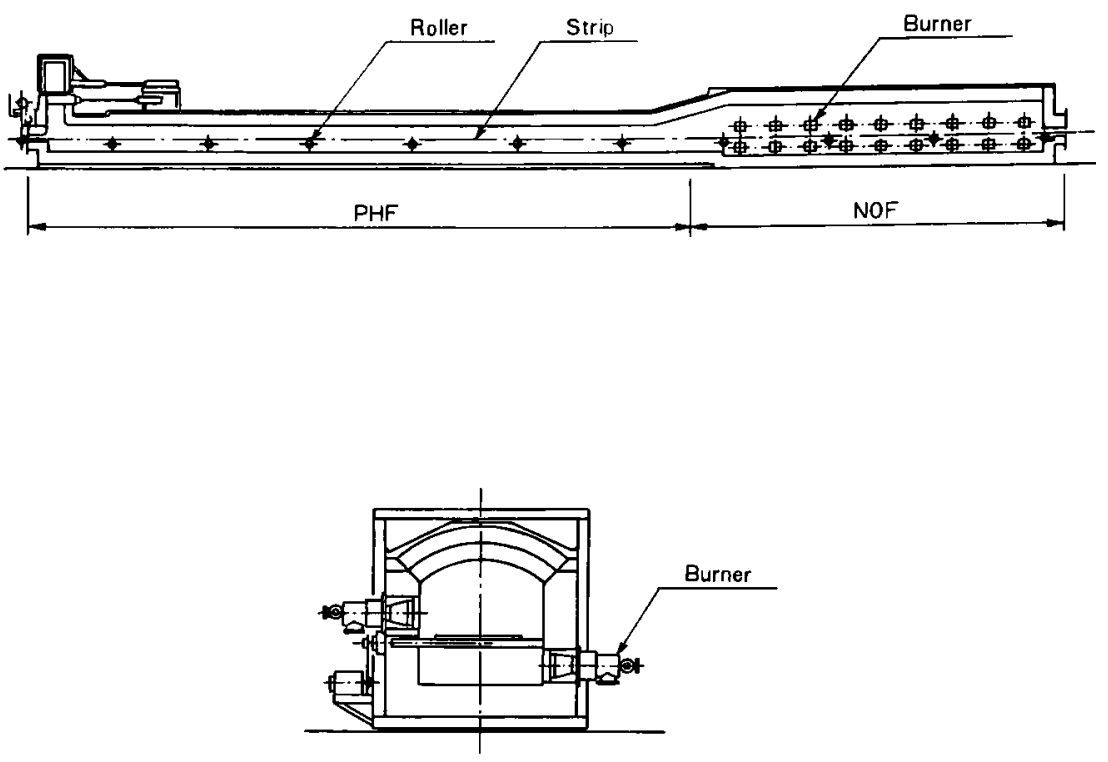

Fig. 1 Non-oxidizing furnace of continuous galvanizing line.

に別かれて扣り，鋼板はPHF 部で予熱され， NOF 部で無酸化状態で加熱される。

無酸化炉の構造は Fig. 1 に示す通りである。

Fig. 1 に示した無酸化炉の伝熱を解析するにあ たって計算を簡略化するために次のような仮定を 行った。

（1）炉は鋼板を境に上下に分割されるが，上下は 対称のbのとして，上部についてのみ計算する。

(2) 炉は長手方向に PHFを 6 等分, NOF を 3 等 分の計 9 等分し，その分割されたジーン内では 炉壁および燃焼ガスの温度は均一なるのとす る。また，鋼板は各ソーン内で直線的な温度分 布をるっているるのとする。

（3）鋼板は内部への熱伝導が無視できる程十分薄 いので厚み方向の温度は均一とする。また，幅 方向の温度分布も均一とする。

（4）各バーナの然焼はそのソーン内で完了するも

注)ゾーンとは連続量を数值計算上離散化した単位 （たとえば，FEM では有限要素，FDM では差分メ ッシニに対応する）であり炉内の等温とみなすこと ができる潋小な区分。面ソーンとは炉内壁面および 鋼板表面の微小面積，ガスソーンとは炉内空間の微 小立方体を示す。
のとする。

（5）燃料はガス然料とし輝炎放射はないものとす る。

以上のよ 5 な仮定に基ついて，炉形は Fig. 2 の よらにモデル化された。またこの炉の標準的な 仕様は Table 1 に示された通りである。

\section{2 計 算 方 法}

\subsection{1 概 要}

ソーン法は炉内を(世渞小なガスゾーンと面ゾー ンに分割し，その拉のおのの微小ゾーン間ごとの エネルギの授受から温度分布を計算する方法であ る。最初に，直接交换面積を計算する。直接交換 面積は，各ゾーン間の反射を考慮しない放射层熱 の熱交換係数を意味する。

次に直接交換面積から炉内壁面での多重反射を 考虑した全交換面積を求める（值接交換面積，全 交換面積については2.2.3節に詳述)。そして，全 交換面積から求まる放射伝熱に，さらに炬内の放 射以外の熱移動メカニズムである対流伝熱，燃焼 による発熱，ガス流れによる顕熱の移動などを加 えて各ゾーンのエネルギーバランス式をたてる。 各ゾーンごとのエネルギーバランス式を連立方程 式として解くことにより各ゾーンの温度, すなわ 

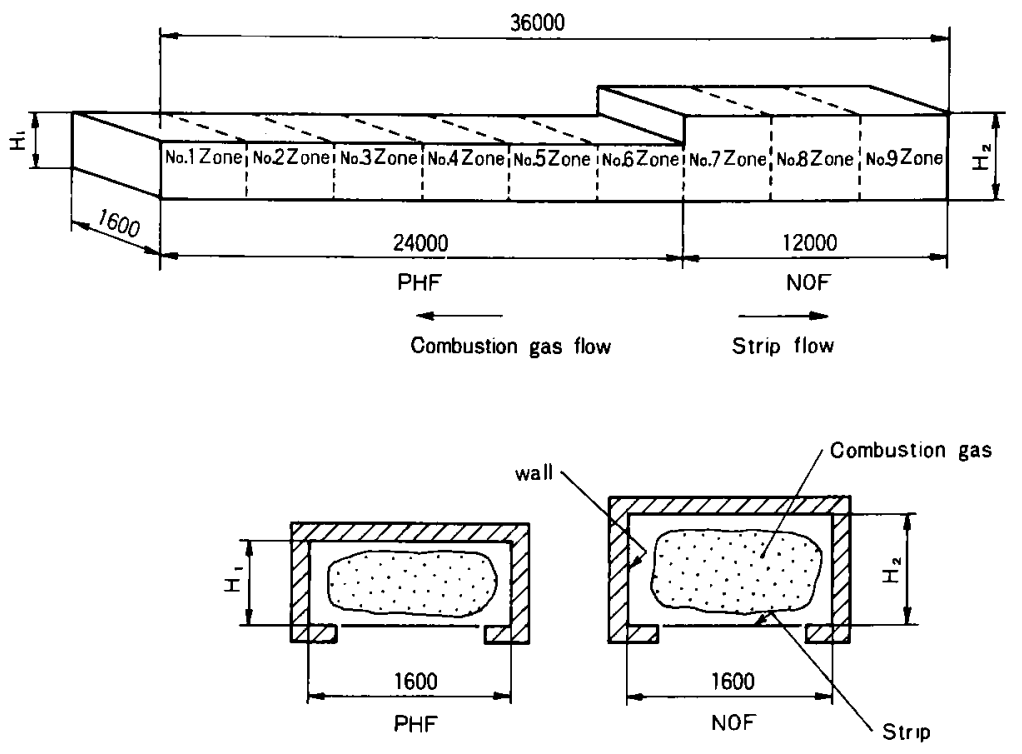

Fig. 2 Model of non-oxidizing furnace.

Table 1. Basic specification of non-oxidizing furnace.

\begin{tabular}{|c|c|}
\hline Furnace shape & Refer to Fig.1 \\
\hline Furnace width $\times$ length & $1600 \mathrm{~mm}^{\mathrm{w}} \times 36000 \mathrm{~mm}^{\mathrm{L}}$ \\
\hline Strip size & $0.27 \mathrm{~mm}^{\mathrm{t}} \times 914 \mathrm{~mm}^{\mathrm{w}}$ \\
\hline Line speed & $170 \mathrm{~m} / \mathrm{min}$ \\
\hline Production capacity & $19.6 \mathrm{t} / \mathrm{h}$ \\
\hline Fuel & Butane air mixed gas $\left(\mathrm{HI}=9800 \mathrm{kcal} / \mathrm{m}^{3} \mathrm{~N}\right)$ \\
\hline Heat input & $\begin{array}{l}921 \times 10^{3} \mathrm{kcal} / \mathrm{h} \\
\qquad \begin{array}{l}\text { No. } 8 \text { zone }: 456 \times 10^{3} \mathrm{kcal} / \mathrm{h} \\
\text { No. } 9 \text { zone }: 465 \times 10^{3} \mathrm{kcal} / \mathrm{h}\end{array}\end{array}$ \\
\hline Combustion air temperature & $\mathrm{Ta}=180^{\circ} \mathrm{C}$ \\
\hline Air ratio & $\mathrm{m}=0.95$ \\
\hline \multirow[t]{2}{*}{ Emissivity } & Wall $\varepsilon=0.8$ \\
\hline & Strip \\
\hline
\end{tabular}

ち炉内の温度分布を求めることがでさる。

各ステップに批ける計算方法は次に述べる通り

であるが, 全体のフローチャートをFig. 3 に示 †。

\subsection{2 燃焼ガスのモデル化}

一般に然焼ガスはいくつかの波長領域だけで吸 収，放射を行ら選択放射の性質をむっており，単 なる灰色ガス（吸収係数が一定のガス）としては 表わせない。そこで，吸収保数の異なる $\mathrm{n}$ 種の灰 色ガスが混在しているものとして，放射率 $\varepsilon_{\mathrm{g}}$ は次
式のよらに表わされる。

$$
\begin{aligned}
& \varepsilon_{\mathrm{B}}=\sum_{\mathrm{l}=0}^{\mathrm{n}} \mathrm{a}_{\mathrm{l}}\left(1-\mathrm{e}^{-\mathrm{kIx}}\right) \\
& \sum_{i=0}^{n} a_{l}=1
\end{aligned}
$$
対する重み係数である。X（ガス厚さ）と $\varepsilon_{\mathrm{g}}$ の関 係は種々提示されているが,ここではSchackの式 を使用した。

実ガスのデータに基づいて，(1)式の $\mathrm{a}_{i}, \mathrm{~K}_{1}$ を算出 すると, $a_{1}$ は温度により变化するが, K、はほとんど 変化しないことがわかる。したがって(1)式はK、を 
一定とし，a だけを温度の関数として， $\mathrm{n}=2$ とし て，次のよらに表わすこととした。

$$
\varepsilon_{g}=a_{0}\left(T_{g}\right)+a_{1}\left(T_{g}\right) \cdot\left(1-e^{-K_{1} x}\right)+a_{2}\left(T_{g}\right) \cdot
$$$$
\left(1-\mathrm{e}^{-\mathrm{K}_{2} \mathrm{x}}\right)
$$

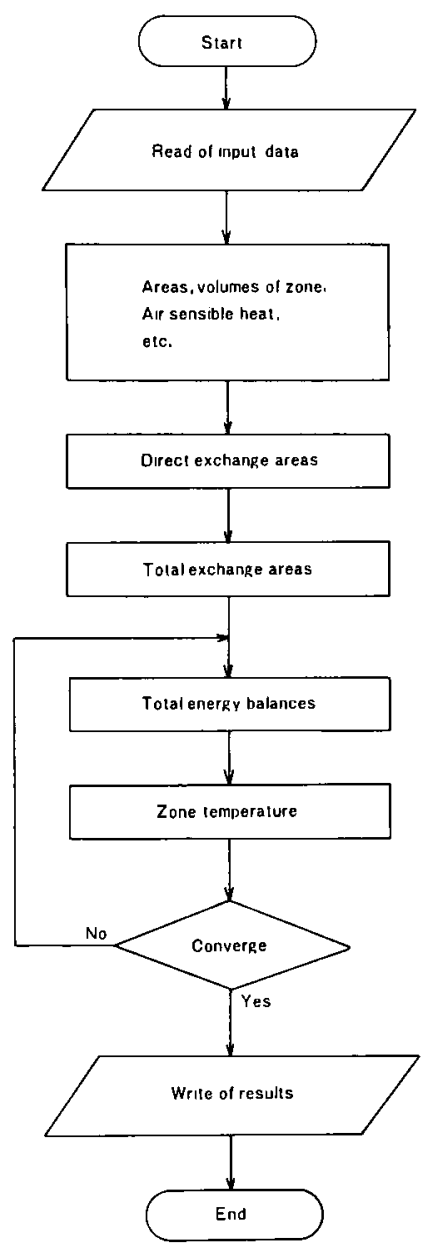

Inpul data

$F^{\prime}$ ce dimension

Strip size

Line speed

Thermal constants

elc.

ここで， $\mathrm{T}_{\mathrm{g}}$ はガスの絶対温度， $a_{0}$ は透明領域の

重み係数である。

\subsection{3 直接交換面程と全交換面皘}

(1) 直接交換面積

ゾーン i から放射したエネルギーの5ちソーン

$\mathrm{j}$ に到達するエネルギーの割合を示す係数を i

- j 間の直接交換面積という。直接交換面積は,

黒体表面で囲まれた空間のなかに灰色ガスが充満

している場合に相当し，以下のよ5に求めること ができる。(Fig. 4 参照)

(1)面一面間直接交換面積 $\left(\overline{\mathrm{S}_{\mathrm{ij}}}\right)$

$$
\overline{\mathrm{S}_{\mid} \mathrm{S}_{\mathrm{j}}}=\int_{\mathrm{A} 1} \int_{\mathrm{A} J} \frac{\cos \theta_{1} \cos \theta_{\mathrm{j}} \mathrm{e}^{-\mathrm{Kr}}}{\pi \mathrm{r}^{2}} \mathrm{dA} \mathrm{A}_{1} \mathrm{dA}
$$

(2)ガスー面間直接交換面積 $\left(\overline{\mathrm{g}_{\mathrm{IS}} \mathrm{S}}\right)$

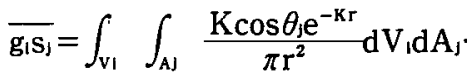

(3)ガスーガス間直接交換面積 $\left(\overline{\mathrm{g}_{\mathrm{g}} \mathrm{g}}\right)$

$$
\overline{g_{1} g_{j}}=\int_{v_{1}} \int_{v_{j}} \frac{K^{2} e^{-K r}}{\pi r^{2}} d v_{l} d v_{j}
$$

ここで， $\mathrm{s}$ は面を， $\mathrm{g}$ はガスを表うす。 $\mathrm{dA}, \mathrm{dV}$

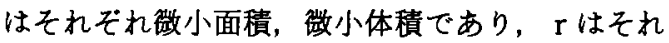
らの間の距離である。 である。

実際の計算では(4)，(5)，(6)式は区分求積法によ って求める。

（2）全交換面積

ある面から放射し面間で多重反射の結果，他の 面に到達するエネルギーの割合を示す係数を全交 換面積 $\overline{\mathrm{S}_{\mathrm{S}} \mathrm{S}}$ という。

いま壁は灰色であり，ガスる灰色である系の面 ゾーンj 上に拈ける放射エネルギーバランスを考 える。Fig. 5 に示すよらに,すべての面ゾーンおよ びガスソーンから面ソーン $\mathrm{j} に$ 到達するエネルギ

Fig. 3 Flow chart.

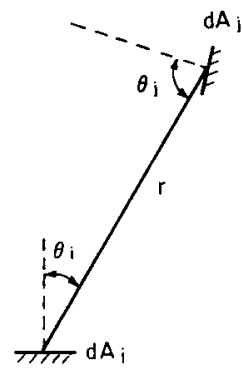

(a) surface-surface

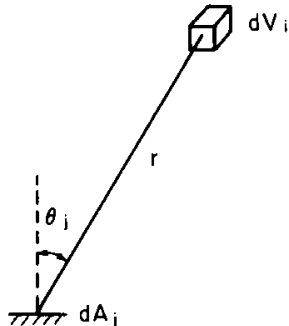

(b) gas-surface

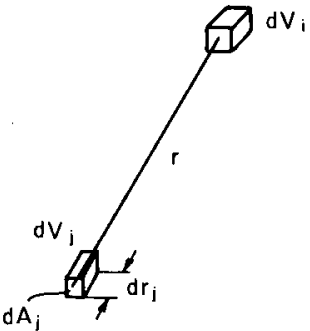

(c) gas-gas

Fig. 4 Direct exchange area between elements. 


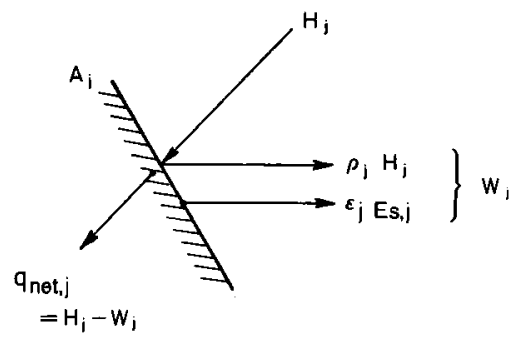

Fig. 5 Energy balance at surface zone.

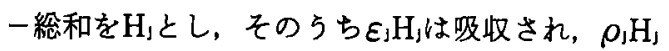

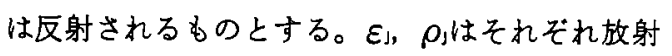

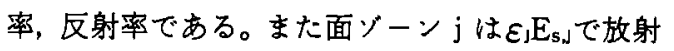
しているとすると，jから射出されるエネルギー フラックス W小次のように表すことができる。

$W_{\mathrm{J}}=\varepsilon_{\mathrm{j}} \mathrm{E}_{\mathrm{s}, \mathrm{j}}+\rho_{\mathrm{J}} \mathrm{H}_{\mathrm{j}}$ (7)

ここで, $\mathrm{E}_{\mathrm{s}, \mathrm{U}}$ 面ゾーン $\mathrm{j} に$ に㧍りる黒体放射エネ ルギーである。

面ゾーンうに到達するエネルギーフラックス は，すべてのゾーンから放射されるエネルギーフ ラックスと直接交換面積の積の和となり，次の関 係が成り立つ。

$$
\mathrm{A}_{\mathrm{J}} \mathrm{H}_{\mathrm{J}}=\sum_{\mathrm{T}} \overline{\mathrm{s}_{\mathrm{I}} \mathrm{s}_{\mathrm{j}}} W_{1}+\sum_{\mathrm{i}} \overline{\mathrm{g}_{\mathrm{I}} \mathrm{s}_{\mathrm{J}}} \mathrm{E}_{\mathrm{g} .1}
$$

したがって，面ゾーン jから放射されるエネルギ 一は次のよらに表される。

$$
\begin{aligned}
& A_{j} W_{j}=A_{j} \varepsilon_{j} E_{s . j}+A_{\jmath} \rho_{j} H_{j}
\end{aligned}
$$

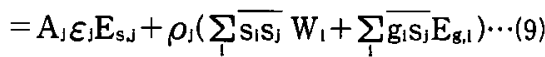

(9)の式は，空間内の面げーン j における放射エ ネルギーのパランスを示しておりり，書き直すと次 の上らになる。

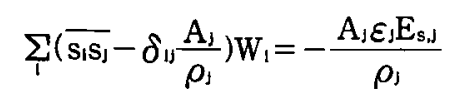$$
-\sum_{1} \overline{\mathbf{g}_{\mathbf{S}} \mathbf{S}_{\mathrm{j}}} \mathrm{E}_{\mathbf{g}_{1},}
$$
(10)

$$
\mathrm{i}=\mathrm{j} \text { のとき, } \delta_{\mathrm{IJ}}=1
$$$$
\mathrm{i} \neq \mathrm{j} \text { のとき, } \delta_{\mathrm{J}}=0
$$

(10)式は，すべての面ジーンにおいて成り立ち， $\mathrm{n}$ 個の連立方程式となるが，これをるとにして以 下のよ5に全交換面積が求められる。 (1)ガス一面間全交換面積 ( $\overline{\mathrm{G}_{I} \mathrm{~S}_{\mathrm{J}}}$ )

$$
\overline{\mathrm{G}_{\mathrm{I}} \mathrm{S}_{\mathrm{J}}}=\frac{\mathrm{A}_{\mathrm{J}} \varepsilon_{\mathrm{J}}}{\rho_{\mathrm{J}}} \mathrm{g}_{\mathrm{J}} \mathrm{W}_{\mathrm{J}}
$$

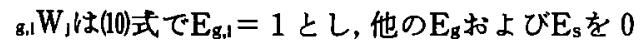

として求めることができる。

(2)面一面間全交換面積 $\left(\overline{\mathrm{S}_{\mathrm{S}} \mathrm{S}}\right)$

$$
\overline{\mathrm{S}_{\mathrm{I}} \mathrm{S}_{\mathrm{J}}}=\frac{A_{\mathrm{J}} \varepsilon_{\mathrm{J}}}{\rho_{\mathrm{j}}}\left(\mathrm{s}_{\mathrm{s}, \mathrm{W}} \mathrm{W}_{\mathrm{j}}-\delta_{\mathrm{IJ}} \varepsilon_{\mathrm{l}}\right)
$$

$s, W, は(10)$ 式で $E_{s, 1}=1$ とし，他のすべての $E_{s} お よ$

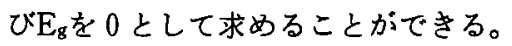
(3)ガスーガス間全交換面積 $\left(\overline{\mathrm{G}_{\mathrm{l}} \mathrm{G}_{\mathrm{J}}}\right)$

$$
\overline{\mathrm{G}_{1} \mathrm{G}_{j}}=\overline{\mathrm{g}_{1} \mathrm{~g}_{j}}+\sum_{\mathrm{k}} \overline{\mathrm{s}_{\mathrm{k}} \mathrm{g}_{\mathrm{l}}} \cdot{ }_{\mathrm{g}_{1} \mathrm{~W}_{\mathrm{k}}}
$$

（3）方向性全交換面積

次に，灰色ガスの場合の全交換面積に基いて， 実ガスの全交換面積，すなわち方向性全交換面積 $\left(\overrightarrow{\mathrm{S}_{1} \mathrm{~S}_{1}}, \overrightarrow{\mathrm{S}_{1} \mathrm{G}_{\mathrm{J}}}, \overrightarrow{\mathrm{G}_{\mathrm{S}} \mathrm{S}_{\mathrm{j}}}, \overrightarrow{\mathrm{G}_{1} \mathrm{G}_{\mathrm{j}}}\right)$ を求める。

$$
\begin{aligned}
& \overrightarrow{S_{i} S_{j}}=\sum_{k=0}^{n}\left[\left(a_{s, k}\left(T_{s, 1}\right)\right]\left(\overline{S_{1} S_{j}}\right)_{k} \cdots \cdots \cdots \cdots \cdots \cdots \cdots(14)\right. \\
& \overrightarrow{\mathrm{S}_{\mathrm{j}} \mathrm{G}_{\mathrm{j}}}=\sum_{\mathrm{k}=0}^{\mathrm{n}}\left[\mathrm{a}_{\mathrm{s}, \mathrm{k}}\left(\mathrm{T}_{\mathrm{s}, \mathrm{l}}\right)\right]\left(\overline{\mathrm{S}_{\mathrm{j}} \mathrm{G}_{j}}\right)_{\mathrm{k}} \cdots \cdots \cdots \cdots \cdots \cdots \cdots(15)
\end{aligned}
$$

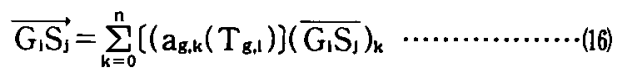

$$
\begin{aligned}
& \overrightarrow{\mathrm{G}_{1} \mathrm{G}_{j}}=\sum_{k=0}^{\mathrm{n}}\left[\mathrm{a}_{\mathrm{g}, \mathrm{k}}\left(\mathrm{T}_{\mathrm{g}, \mathrm{l}}\right)\right]\left(\overline{\mathrm{G}_{1} \mathrm{G}_{\mathrm{j}}}\right)_{\mathrm{k}}
\end{aligned}
$$

方向性全交換面積は，放射源の温度の関数とな る。

$$
\text { 2.2.4 全エネルギーバランス }
$$

前述の方向性全交換面積により各ゾーン間の放 射エネルギーの交換量が求をる。しかし炉内には 放射伝熱のほかに，対流伝熱，然焼に上る発熱， ガス顕熱の移動などの熱的現象もある。したがっ て各ゾーンの温度分布は，これらのすべての熱的 現象を含めた全ェネルギーバランス式により求め られる。

(1)面ゾーンにおけるェネルギーバランス

面ソーンiにおけるエネルギーハラランスは次の ようになる。

$\sum_{\mathrm{j}} \overrightarrow{\mathrm{S}_{\mathrm{S}} \mathrm{S}_{\mathrm{l}}} \mathrm{E}_{\mathrm{s}, \mathrm{J}}+\sum_{\mathrm{J}} \overrightarrow{\mathrm{G}_{\mathrm{J}} \mathrm{S}_{\mathrm{l}}} \mathrm{E}_{\mathrm{g}, \mathrm{J}}-\mathrm{A}_{1} \varepsilon_{1} \mathrm{E}_{\mathrm{s}, \mathrm{l}}+\alpha_{1} \mathrm{~A}_{1}\left(\mathrm{~T}_{\mathrm{g} . \mathrm{k}}\right.$ $\left.-T_{s, 1}\right)=\dot{Q}_{\text {net, },}$ $\cdot(18)$

ここで, $\alpha_{1} \mathrm{~A}_{1}\left(\mathrm{~T}_{\mathrm{g}, \mathrm{k}}-\mathrm{T}_{\mathrm{s}, \mathrm{l}}\right)$ 項は隣接するガスゾー ン k から面ジーン i への対流熱移動を示し, $\dot{\mathrm{Q}}_{\mathrm{net}, \mathrm{I}}$ は炉壁からの放散熱量あるいは鋼板への正味层熱 量を示す。

(2)ガスゾーンにおけるェネルギーバランス ガスソーンiにおけるェネルギーバランスは, 次のよらになる。 $\sum_{j} \overrightarrow{G_{j} G_{l}} E_{g, J}+\sum_{j} \overrightarrow{S_{\jmath} G_{1}} E_{s, ~}-4 \sum_{n} a_{g, n} K_{n} V_{l} E_{g, l}+\dot{Q}_{e, l}$ $+\dot{\mathrm{Q}}_{\mathrm{f}, \mathrm{l}}=0$ $\cdot(19)$ 
Table 2. Discharge temperature of model furnace.

\begin{tabular}{|c|c|c|c|c|c|c|c|}
\hline \multirow{2}{*}{$\begin{array}{l}\text { Furnace } \\
\text { width } \\
(\mathrm{mm})\end{array}$} & \multirow{2}{*}{$\begin{array}{l}\text { Furnace } \\
\text { length } \\
(\mathrm{mm})\end{array}$} & \multicolumn{2}{|c|}{$\begin{array}{c}\text { Furnace height } \\
\text { (mm) }\end{array}$} & \multirow{2}{*}{$\begin{array}{l}\text { Strip } \\
\text { width } \\
(\mathrm{mm})\end{array}$} & \multicolumn{2}{|c|}{ Emissivity(-) } & \multirow{2}{*}{$\begin{array}{l}\text { Discharge } \\
\text { temperature } \\
\text { ('C) }\end{array}$} \\
\hline & & $\overline{\mathrm{H}_{1}}$ & $\mathrm{H}_{2}$ & & Strip & Wall & \\
\hline 1600 & 36000 & 400 & 1100 & 914 & 0.3 & 0.80 & 571.8 \\
\hline
\end{tabular}

Table 3. Effect of furnace height on discharge temperature.

\begin{tabular}{|c|c|c|c|c|c|c|c|}
\hline \multirow{2}{*}{$\begin{array}{l}\text { Furnace } \\
\text { width } \\
(\mathrm{mm})\end{array}$} & \multirow{2}{*}{$\begin{array}{l}\text { Furnace } \\
\text { length } \\
(\mathrm{mm})\end{array}$} & \multicolumn{2}{|c|}{$\begin{array}{c}\text { Furnace height } \\
\text { (mm) }\end{array}$} & \multirow{2}{*}{$\begin{array}{l}\text { Strip } \\
\text { width } \\
(\mathrm{mm})\end{array}$} & \multicolumn{2}{|c|}{ Emissivity(-) } & \multirow{2}{*}{$\begin{array}{l}\text { Discharge } \\
\text { temperature } \\
\left({ }^{\circ} \mathrm{C}\right)\end{array}$} \\
\hline & & $\mathrm{H}_{1}$ & $\mathrm{H}_{2}$ & & Strip & Wall & \\
\hline \multirow{4}{*}{1600} & \multirow{4}{*}{36000} & 400 & 1100 & \multirow{4}{*}{914} & \multirow{4}{*}{0.3} & \multirow{4}{*}{0.80} & 571.8 \\
\hline & & \multicolumn{2}{|c|}{1100} & & & & 566.9 \\
\hline & & \multicolumn{2}{|c|}{1300} & & & & 564.9 \\
\hline & & \multicolumn{2}{|c|}{900} & & & & 567.7 \\
\hline
\end{tabular}

ここで, $\dot{Q}_{\mathrm{e}, 1}$ はガスソーンを流れるガスの顕熱 の移動量に，隣接面ゾーンからの対流熱移動量を

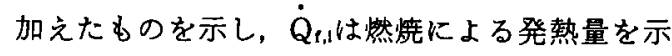
す。

エネルギーバランス式は温度の 5 次以上の連立 方程式となる。ここでは反復法により計算した。 このプログラムは約3500ステップであり，計算 時間の一例を示せば約16分であった。

\section{3. 計 算 結 果}

CGLの伝熱効率に影響を与えるパラメータと して多くのものが考点られる。ここでは，そのな かでも特に大きな要因と考えられる炉の高さ，放 射率, 燃料, 空気比, 鋼板の板幅についてパラ丸 一タを変化させて，その影響を調べた。比較の方 法としては3.6節の板幅による影響を除いて, 炬へ の投入熱量を一定とし，鋼板の抽出温度の比較を 行っている。抽出温度が高いといらことは, 炉内 の伝熱効率が高いことを示し，抽出温度を一定之 した場合には炉の原単位が低くなることを示して いる。

\section{1 モデル炉計算結果}

Table 1 に示したモデル炉の計算結果をTable 2 に示す。ぬた, Fig. 6 にこの場合の計算加熱曲線 を示した。

\section{2 炉高の影噌}

上記のモデル炬で高さを変占た場合に鋼板の抽

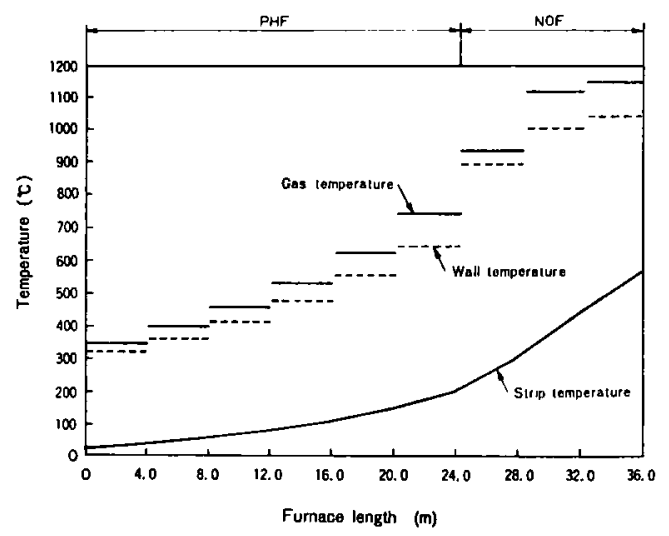

Fig. 6 Example of temperature distribution of gas and wall surface and heating curve of strip.

出温度がどのように変化するか計算した。炉の高 さは全炉長で一定の高さとし，モデル炬より高い 場合と低い場合の両方のケースで計算した。

この計算結果から炉の高さはTable 3 に示す計 算範囲内では伀熱効率にあまり大きな影響を与え ないが，高すぎると抽出温度がさがって伀熱効率 が悪くなることがわかる。また，モデル妒のよう にPHF 部の高さを低くした場合の抽出温度が最 も高いことがわかる。これは, NOF部に比べて PHF部の天井が低いため，高温部（燃焼ゾーン） であるNOF部から低温部であるPHF部への放射 
Table 4. Effect of emissivity on discharge temperature.

\begin{tabular}{|c|c|c|c|c|c|c|c|}
\hline \multirow{2}{*}{$\begin{array}{l}\text { Furnace } \\
\text { width } \\
\text { (mm) }\end{array}$} & \multirow{2}{*}{$\begin{array}{l}\text { Furnace } \\
\text { length } \\
\text { (mm) }\end{array}$} & \multicolumn{2}{|c|}{$\begin{array}{l}\text { Furnace height } \\
(\mathrm{mm})\end{array}$} & \multirow{2}{*}{$\begin{array}{l}\text { Strip } \\
\text { width } \\
\text { (mm) }\end{array}$} & \multicolumn{2}{|c|}{ Emissivity(-) } & \multirow{2}{*}{$\begin{array}{l}\text { Discharge } \\
\text { temperature } \\
\left({ }^{\circ} \mathrm{C}\right)\end{array}$} \\
\hline & & $\mathrm{H}_{1}$ & $\mathrm{H}_{2}$ & & Strip & Wall & \\
\hline \multirow{5}{*}{1600} & \multirow{5}{*}{36000} & \multirow{5}{*}{400} & \multirow{5}{*}{1100} & \multirow{5}{*}{914} & 0.3 & 0.80 & 571.8 \\
\hline & & & & & 0.3 & 0.60 & 569.5 \\
\hline & & & & & 0.3 & 0.90 & 572.7 \\
\hline & & & & & 0.25 & 0.80 & 559.9 \\
\hline & & & & & 0.35 & 0.80 & 582.4 \\
\hline
\end{tabular}

Table 5. Effect of fuel on discharge temperature.

\begin{tabular}{|c|c|c|c|c|c|c|}
\hline \multirow{2}{*}{$\begin{array}{l}\text { Furnace } \\
\text { width } \\
(\mathrm{mm})\end{array}$} & \multirow{2}{*}{$\begin{array}{l}\text { Furnace } \\
\text { length } \\
(\mathrm{mm})\end{array}$} & \multicolumn{2}{|c|}{$\begin{array}{l}\text { Furnace height } \\
\text { (mm) }\end{array}$} & \multirow{2}{*}{$\begin{array}{l}\text { Strip } \\
\text { width } \\
\text { (mm) }\end{array}$} & \multirow{2}{*}{ Fuel } & \multirow{2}{*}{$\begin{array}{l}\text { Discharge } \\
\text { temperature } \\
\text { ('C) }\end{array}$} \\
\hline & & $\mathrm{H}_{\mathrm{l}}$ & $\mathrm{H}_{2}$ & & & \\
\hline \multirow{2}{*}{1600} & \multirow{2}{*}{36000} & \multirow{2}{*}{400} & \multirow{2}{*}{1100} & \multirow{2}{*}{914} & APG & 571.8 \\
\hline & & & & & COG & 572.2 \\
\hline
\end{tabular}

Table 6. Effect of air ratio on discharge temperature.

\begin{tabular}{|c|c|c|c|c|c|c|}
\hline \multirow{2}{*}{$\begin{array}{l}\text { Furnace } \\
\text { width } \\
(\mathrm{mm})\end{array}$} & \multirow{2}{*}{$\begin{array}{l}\text { Furnace } \\
\text { length } \\
(\mathrm{mm})\end{array}$} & \multicolumn{2}{|c|}{$\begin{array}{c}\text { Furnace height } \\
(\mathrm{mm})\end{array}$} & \multirow{2}{*}{$\begin{array}{l}\text { Strip } \\
\text { width } \\
(\mathrm{mm})\end{array}$} & \multirow{2}{*}{$\begin{array}{l}\text { Air ratio } \\
(-)\end{array}$} & \multirow{2}{*}{$\begin{array}{l}\text { Discharge } \\
\text { temperature } \\
\left({ }^{\circ} \mathrm{C}\right)\end{array}$} \\
\hline & & $\mathrm{H}_{1}$ & $\mathrm{H}_{2}$ & & & \\
\hline \multirow{3}{*}{1600} & \multirow{3}{*}{36000} & \multirow{3}{*}{400} & \multirow{3}{*}{1100} & \multirow{3}{*}{914} & 0.9 & 550.8 \\
\hline & & & & & 0.95 & 571.8 \\
\hline & & & & & 0.98 & 584.3 \\
\hline
\end{tabular}

伝熱量が少なくなり、NOF部のガスおよび壁面が 高温に保たれるためと思われる。一般に加熱側温 度が高盜のほど伝熱効率は良いと言われている。

\section{3 放射率の影響}

炉壁扰よび鋼板の放射率を変えて抽出温度を求 めた結果を Table 4 に示す。

Table 4 の結果から，炉壁の放射率は炉の伝熱 効率にあまり影劉を与えないが，炉壁の放射率が 高い方が伀熱効率が良くなることがわかる。また， 鋼板の放射率は炉の伝熱効率に大きな影響をおよ ぼし，当然のことながら，放射率が高い方が伀熱 効率が良くなっている。

\section{4 燃料の種類による影㯰}

モデル炉の然料はブタンェアミックスガス （APG）であるが，层熱効率を比較するために COGの場合の抽出温度を求めた結果をTable 5
に示す。

$\mathrm{APG}$ とCOGの投入熱量が同じになるように して計算したものであるが，両者の伝熱効率はほ とんど変わらないことがわかる。

\section{5 空気比の影䪪}

燃料投入量を一定として，空気比を变化させた 場合の鋼板の抽出温度の違いを求めた。その結果 は Table 6 に示す通りである。

\section{6 鋼板の板幅変化の影翼}

炉内幅は一定とし，板幅が变化した場合の抽出 温度の違いを求めた。この場合, ラインスピード は一定とし，然料の投入量は板幅に比例するもの とした。

Table 7 の結果より，カバーレシオの高くなる 板幅の広い場合の方が抽出温度が高くなることが わかる。これは，側壁に近い部分の鋼板の全交換 
Table 7. Effect of strip width on discharge temperature.

\begin{tabular}{|c|c|c|c|c|c|c|c|}
\hline \multirow{2}{*}{$\begin{array}{l}\text { Furnace } \\
\text { width } \\
\text { (mm) }\end{array}$} & \multirow{2}{*}{$\begin{array}{l}\text { Furnace } \\
\text { length } \\
(\mathrm{mm})\end{array}$} & \multicolumn{2}{|c|}{$\begin{array}{l}\text { Furnace height } \\
(\mathrm{mm})\end{array}$} & \multirow{2}{*}{$\begin{array}{l}\text { Strip } \\
\text { width } \\
(\mathrm{mm})\end{array}$} & \multicolumn{2}{|c|}{ Emissivity(-) } & \multirow{2}{*}{$\begin{array}{c}\text { Discharge } \\
\text { temperature } \\
\text { (C) }\end{array}$} \\
\hline & & $\mathrm{H}_{1}$ & $\mathrm{H}_{2}$ & & Strip & Wall & \\
\hline \multirow{3}{*}{1600} & \multirow{3}{*}{36000} & \multirow{3}{*}{400} & \multirow{3}{*}{1100} & 600 & \multirow{3}{*}{0.3} & \multirow{3}{*}{0.8} & 551.8 \\
\hline & & & & 914 & & & 571.8 \\
\hline & & & & 1250 & & & 581.7 \\
\hline
\end{tabular}

面積が大きいことが，平均の抽出温度を高くして いるためである。

燃料投入量を一定とした場合の空気比の変化 は，然焼により発生する熱量が変ってくるために， 鋼板の抽出温度に非常に大きな影響を与えること がかる。当然の結果ながら, 空気比が 1 に近い ほど抽出温度が高くなる。

\section{4. 緒言}

ゾーン法による連続亜鉛メッキ設備の無酸化炉 の伝熱解析用ブログラムを開発し，各種の計算を 行った。計算例では, 炬の高さ, 放射率, 燃料, 空気比, 鋼板の板幅のパラメータを変化させ,そ れによる抽出温度の違いを述べた。

連続垔鉛メッキ設備の設計にあたっては，本ブ ログラムを用いて最適設計を行うことが可能であ り，省エネルギーとコストダウンに力を発揮する
ものと思われる。今後，さらに板厚方向の温度分 布計算を取り入れれば連続鋼片加熱炬についての 解析もでき，本ブログラムは連続炉全般について の有効な設計手段となり得るであろう。

本業務の遂行にあたり，御指導をいただいた大 同特殊鋼物中央研究所，渡辺一雄工学博士，なら びに多大の御協力をいたたいた同機械事業部設計 部，松村一郎，俵博の各氏に深く感謝します。

$$
\text { （文献） }
$$

1) H.C. Hottel, and A.F. Sarofim : Radiative Transfer, (1967), [McGraw-Hill]

2）杉山峻一, 阿部正広：鉄と鋼，67（1981）4, $\mathrm{S} 362$

3）日本鉄鋼協会共同研究会, 熱経済技術部会, 加熱炉伝熱研究小委員会：加熱炉炉内伝熱解 析法の基礎と応用，（1982），[日本鉄鋼協会] 